\title{
О ДОСПЕЛЕОЛОГИЧЕСКОМ ЭТАПЕ РАЗВИТИЯ КАРСТОВОЙ СИСТЕМЫ ЛЕДЯНОЙ ГОРЫ
}

\author{
Н.В. ЛАВРОВА \\ Горный институт УрО РАН, г. Пермь
}

\begin{abstract}
Аннотация: Рассмотрены условия формирования подземного лабиринта Кунгурской Ледяной пещеры на раннем этапе развития. Тектонические, гидрогеологические и геоморфологические условия на границе палеогена и неогена предопределили артезианскую модель формирования первоначальных изолированных пустот. Зоны деформации массива Ледяной горы, возникшие при восстановлении позднепалеозойскоймезозойской трещиноватости, прорабатывались напорными водами на границе отложений, вмещающих спелеоситему, и подстилающих карбонатных отложений на различную высоту. В отдельных случаях происходила перфорация пещерного массива и выход деформационной зоны на поверхность. В результате в карстовую систему открывается доступ инфильтрационных вод, которые, в свою очередь, вносят определенный вклад в преобразование вертикальных структур в пределах ледяно-пещерской пачки - органных труб. Представлены их морфометрические и генетические особенности. Современный подземный ландшафт спелесистемы сформировался при эволюционном развитии карстовой системы при переходе из напорной в безнапорную стадию. Многосторонний дренаж массива Ледяной горы в результате поднятия приводит к потере напора вод филипповского горизонта, формирующего карстовую систему. Соединение отдельных пустот в устьях органных труб происходит в результате растворяющего действия вод горизонтальной циркуляции поступающих в спелеосистему паводковых вод реки Сылвы, а также инфильтрационных и инфлюационных вод с поверхности. Предложенные дополнения к модели фомирования карстовой системы на первоначальном этапе с привлечением результатов многолетних экспериментов, начатых в Кунгурской пещере в 1985 г., по растворимости отложений, вмещающих карстовые пустоты, позволяют разрешать существующие противоречия при подсчете абсолютного возраста спелеосистемы.
\end{abstract}

Ключевые слова: Кунгурская Ледяная пещера; подземный ландшафт; органные трубы; артезианские условия; эволюция развития карстовой системы; напорный горизонт; инфильтрационные воды; спелеосистема; подсчет абсолютного возраста пещеры.

Введение. Платообразный массив Ледяной горы на северо-восточной окраине г. Кунгура площадью около десяти квадратных километров, ограниченный с севера, запада и юга речными долинами рек Сылва и Шаква, на рубеже палеогена и неогена входил в состав низменной аккумулятивной равнины. В это время начала формироваться Кунгурская Ледяная пещера, которая в настоящее время представляет собой лабиринт узких проходов высотой 0,5-1,5 м, соединяющих гроты и галереи высотой 3,0-17,0 м, сформированый по двум взаимно пересекающимся системам трещин северо-восточного и северо-западного простирания. Вся спелеосистема сформирована в гипсо-ангидритах ледянопещерской пачки иренского горизонта кунгурского яруса мощностью 20-25 м, перекрытых доломитами неволинской пачки мощностью 5-15 м и далее рыхлыми неоген-четвертичными породами мощностью до 15-20 м, подстилаемых доломитами филипповского горизонта.

Морфометрические особенности Кунгурской пещеры в массиве Ледяной горы определяются многоэтапным развитием тектонических нарушений на данном участке, a также динамикой сопутствующих им гидрогеологических и геоморфологических условий. На каждом из четырех этапов неоген-четвертичной геолого-тектонической истории территории города и Кунгурской пещеры, в частности выделенных В.Н. Катаевым [3], В.Н. и Г.Н.Дублянскими, представлены особенности развития Кунгурской пещеры с привлечением материалов исследователей 19-20 веков. На первом этапе на самой ранней инверсионной стадии при восстановлении позднепалеозойской-мезозойской трещиноватости в ангидритах ледянопещерской пачки по артезианской модели стали закладываться галереи пракунгурской пещеры. В дальнейшем обрушения сводов привели к 
заполнению пустот обломками, которые преобразовывались в брекчию. Карстовые процессы в четвертичный период развивались в гидратированных гипсоангидритах и брекчиях при периодических вторжениях вод р.Сылвы инфильтрационными и конденсационными водами [5].

Кунгурская Ледяная пещера изучается более 300 лет. Однако до настоящего времени сохраняются некоторые противоречия в представлениях об условиях формирования карстовой системы Ледяной горы. В конце прошлого столетия А.Б. Климчук выявил структурные и морфологические особенности для гипогенного карста, а также критерии их идентификации при развитии карстовых систем в условиях безнапорной циркуляции подземных вод [4]. Рассмотрение геологического строения массива Ледяной горы и гипотезы образования органных труб, распространенных в пещере, с точки зрения эволюции каналово-полостных систем в слоистой структуре в артезианских условиях позволяет по-новому трактовать историю развития Кунгурской пещеры и ее подземного ландшафта.

Эволюция карстовой системы Ледяной горы на примере развития органных труб. Структурно-поисковые скважины, пройденные объединением «Пермнефть» в юговосточной части Пермской области во второй пловине прошлого столетия, дают достаточно полное представление о геологическом строении северной части Уфимского вала Пермско-Башкирского свода, к которому относится территория г. Кунгура и окрестностей. По данным бурения карстовой системе Ледяной горы соответствует блок, смещенный по системе дизъюнктивных нарушений на фоне общего погружения слоистой толщи карбонатно-сульфатных и карбонатных пород иренского и филипповского горизонтов кунгурского яруса, а также артинских карбонатных отложений в западном направлении (рис. 1, 2). По вертикальным и субвертикальным трещинам, образованным в результате послепермских тектонических движений, сформировались обломочные зоны, пронизывающие толщу Ледяной горы на различную высоту.

Воды филипповского водоносного горизонта, залегающего под отложениями ледяно-пещерской пачки, напорные в силу наклонного залегания пород кунгурского яруса, на олигоцен-миоценовом этапе по артезианской модели «прорабатывали» вертикальные зоны деформации в пределах сульфатной ледяно-пещерской пачки до различных уровней. Впоследствии эти зоны преобразуются в органные трубы. В настоящее время в пещере зафиксировано 146 органных труб. Форма их в плане варьирует от круглой или овальной до извилистой сложной, поперечник составляет 110 м, высота до 20 м. Подавляющая часть органных труб «упирается» в плоские плиты карбонатных пород неволинской пачки. Отдельные трубы не доходят до неволинских доломитов и вскрывают верхние слои сульфатных отложений ледяно-пещерской пачки на абсолютных отметках до 130-135 м (грот Шапка Мономаха, три трубы в проходе между гротами Малый Крестовый и Руины недалеко от входа в Озорные повороты). В этом случае органные трубы в поперечнике 1-3 м высотой не более 5 м имеют округлые своды, что свидетельствует о напорной модели их формирования. Последнее подтверждается фрагментами сохранившихся извилистых фидерных каналов в устьях органных труб высотой до 1 м (грот Длинный, грот Великан), образующихся при восходящем движении подземных вод.

В стенах и сводах органных труб на различной высоте часто наблюдаются отпрепарированные крупные обломки вышезалегающих карбонатных пород доломитов неволинской пачки. В единичных случаях в осыпях под органными трубами встречаются доломитовые блоки, размеры которых не соизмеримы с поперечником самой трубы, что исключает их происхождение в результате вывалов сводов из-за действия гравитации, либо размокания под действием инфильтрационных вод (гроты Космический, Метеорный и др.). В данном случае при деформации в массиве происходил захват вышезалегающих пород. 


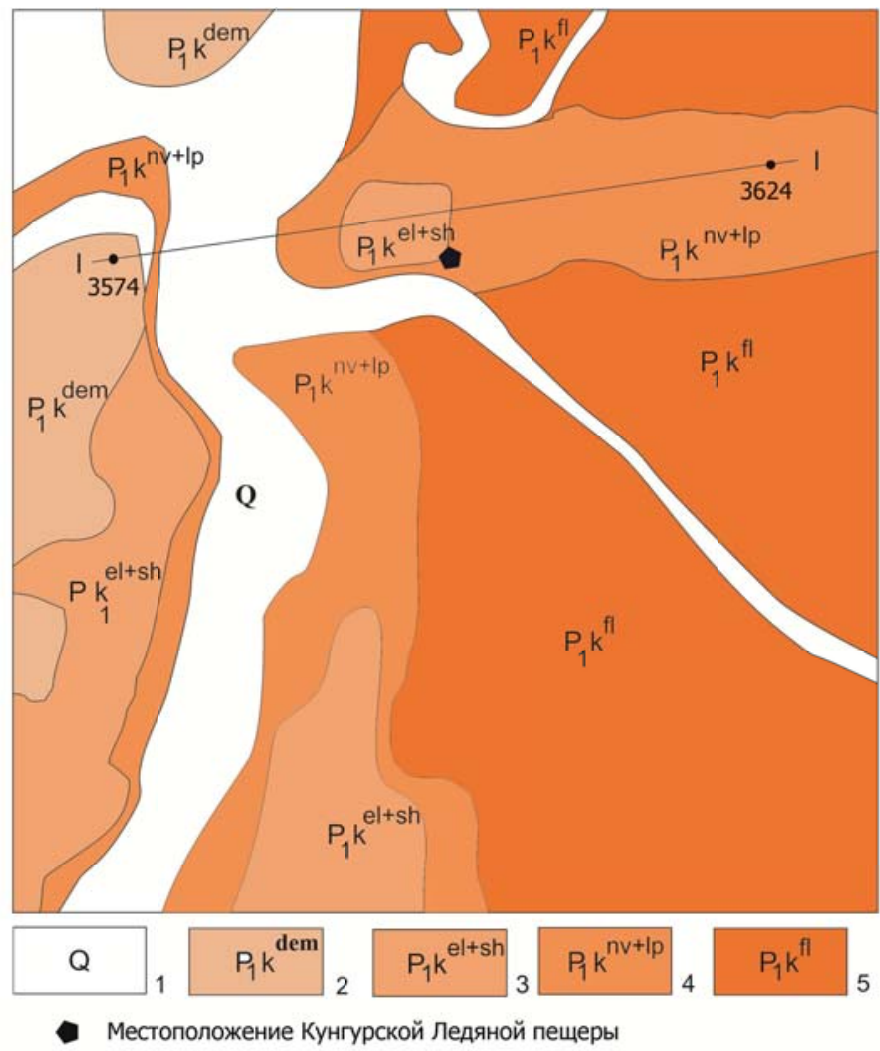

Рис. 1. Схема геологического строения района г. Кунгура [6, испр., дополн.]:

1 - четвертичные отложения: суглинки, супеси, пески, гравий; 2 - демидковская пачка иренского горизонта кунгурского яруса: гипсы, ангидриты; 3 - елкинская пачка: доломиты + шалашнинская пачка: гипсы, ангидриты; 4 - неволинская пачка: доломиты, известняки + ледяно-пещерская пачка: гипсы, ангидриты; 5 филипповский горизонт кунгурского яруса: известняки, доломиты

Абсолютная отметка свода грота Космического, расположенного в центре пещерного поля, составляет 140 м. Своды еще трех гротов - Вышка I, Вышка II и Эфирный - доходят до данной отметки. Но в отличие от них, в гроте Космический выше потолка прослеживается узкая субвертикальная крупноглыбовая обвальная зона, видимая протяженность 10 м, ширина до 3 м. С учетом глубины воронки на поверхности, в этой точке происходит «перфорация» - выход обломочной зоны на поверхность, где локализуется сток дождевых и талых вод. На безнапорной стадии формирования пещеры инфильтрационные воды растворяли сульфатные обломки в пределах деформированной зоны. Менее растворимые карбонатные обломки перемещались, создавая свободное пространство на границе ледяно-пещерской и неволинской пачек. Теперь капли инфильтрационных вод падали с большой высоты, достаточной для формирования ровных вертикальных стен органных труб, которые можно наблюдать в настоящий момент.

Постепенное поднятие территории приводит к обособлению блока Ледяной горы, происходит многосторонний дренаж водораздельного пространства. Воды филипповского горизонта теряют свой напор и начинается формирование собственно лабиринта Кунгурской пещеры инфильтрационными и речными водами. Отдельные пустоты могли сформироваться при растворении обломков в пределах брекчированных зон на границе отложений филипповского и иренского горизонта в устьях будущих органных труб. Основной этап развития пещеры начался с внедрением паводковых вод реки Сылвы. Воды иренского горизонта расширяли уже существующие пустоты и соединяли их узкими проходами, формируя лабиринт. 


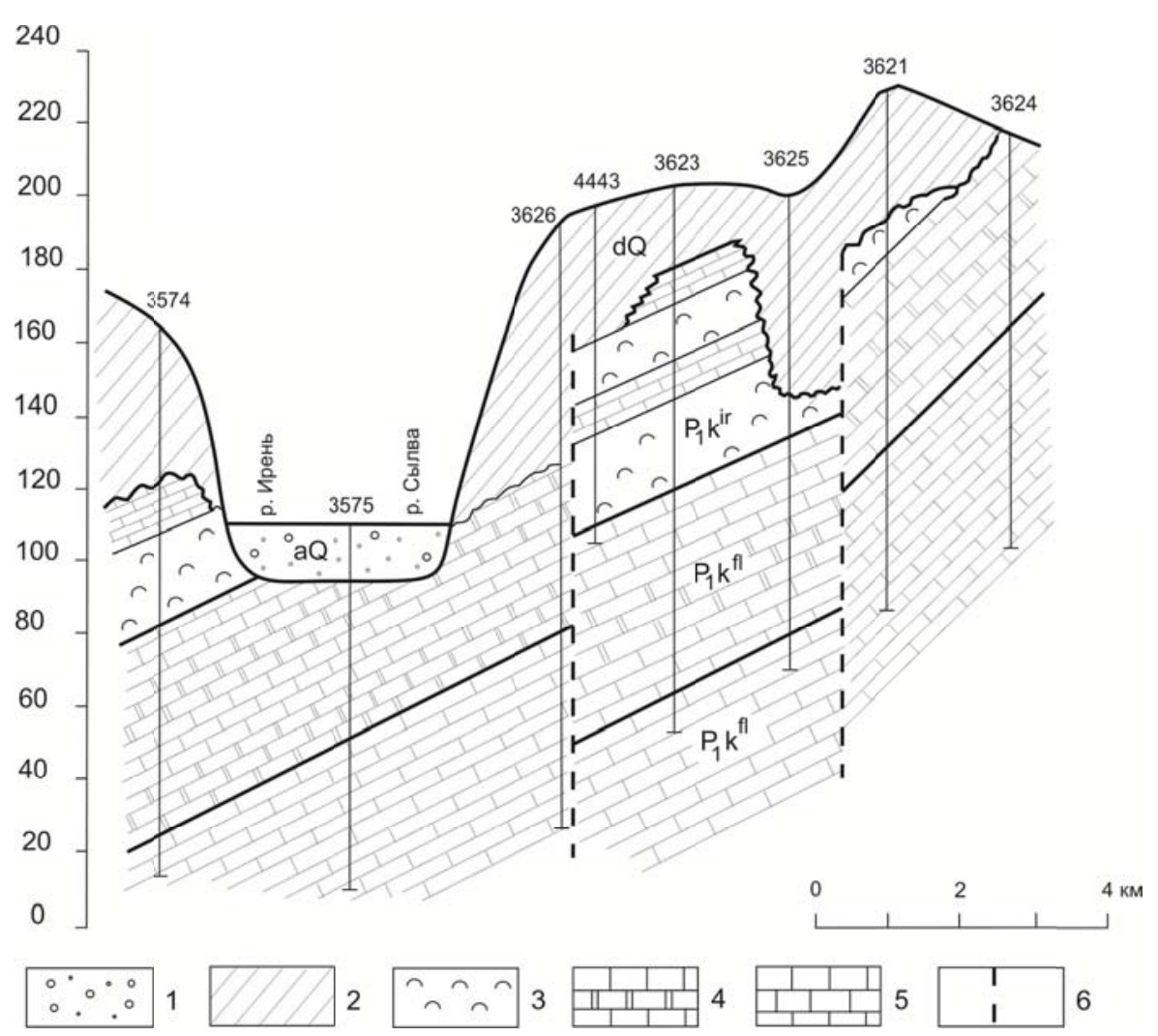

Рис. 2. Геологический профиль по линии I-I:

1- аллювиальные отложения; 2 - элювиально-делювиальные отложения; 3 - гипсы, ангидриты и известняки, доломиты иренского горизонта; 4 - известняки филипповского горизонта кунгурского яруса; 5 - рифовые известняки артинского яруса; 6 - зоны деформации

В настоящее время возраст пещеры синхронизирован со стадиями формирования первой надпойменной террасы и поймы р. Сылвы - 8000-12000 лет [5]. С учетом средней минерализации карстовых вод на выходе из карстующегося массива - 1,85 г/л и внутри $-2,0$ и более г/л, а также объема паводковых вод в пещере приблизительно $10000 \mathrm{~m}^{3}$, вынос сульфатных пород составляет около $8 \mathrm{~m}^{3}$; в пересчете на $1 \mathrm{kм}^{2}$ около $20 \mathrm{~m}^{3}$ в год. Скорость растворения стен полости должна достигать в этом случае 2 мм в год. Данная величина в условиях подземных водоемов достаточно велика и не согласуется с абсолютным возрастом пещеры примерно 10000 лет. Исходя из скорости растворения породы и размера подземных полостей, можно определить абсолютный возраст образования Кунгурской пещеры, что составит примерно 50-60 тысяч лет [1]. Что противоречит очевидному факту - приуроченности всех полостей уровню реки Сылвы.

Фактические данные, полученные в ходе эксперимента по определению величины карстовой денудации, начатого в Кунгурской пещере в 1985 г., позвіолили определить значения интенсивности растворения как непосредственно для стен, так и для образцов, подвешенных в подземных озерах, по разнице весовых значений образцов (мг/сут) и общей потери вещества (мм/год). Интенсивность растворения образцов за этот период составляет 0,05-0,81 мг/сут или 0,10-1,24 мм/год. Скорость растворения стен равна 0,40-0,52 мм/год [2]. С учетом большей скорости растворения обломков, заполняющих пустоты, а не из стен, корреляция возраста пещеры с возрастом террасы в этом случае становится более корректной. 


\title{
Выводы
}

1. Существующая модель развития карстовой системы Ледяной горы на начальном этапе дополнена с позиции особенностей развития гипогенного карста.

2. Фактические данные, полученные в ходе многолетнего эксперимента по изучению растворимости сульфатных отложений в условиях подземных водоемов Кунгурской пещеры, а также современная интерпретация развития органных труб, позволяют определять абсолютный возраст Кунгурской Ледяной пещеры примерно в 10000 лет с разрешением существующих несоответствий по данным изменений значений минерализации подземных вод в различные фазы водности (паводок-межень).

\section{БИБЛИОГРАФИЧЕСКИ СПИСОК}

1. Дорофеев Е.П. Связь водоемов Кунгурской пещеры с рекой Сылвой // Состояние и задачи карстовоспелеологических исследований: тез. докл. Всесоюз. совещ. - Москва, 1975. - С.85-87.

2. Казанцева А.С. Многолетний эксперимент по изучению растворимости сульфатных пород в Кунгурской Ледяной пещере // Вестн. Перм. ун-та. Сер. Геология. - 2018. - Т. 17, № 2. - С. 105-111. DOI: $10.17072 /$ psu.geol.17.2.105.

3. Катаев В.Н. Структурно-тектонические условия формирования Кунгурской пещеры // Пещеры. Итоги исследований: Межвуз. сб.науч. тр. - Пермь, 1993. - Вып.23-24. - С.121-130.

4. Климчук А.Б. Гипогенный спелеогенез, его гидрогеологическое значение и роль в эволюции карста. Симферополь: Изд-во ДИАЙПИ, 2013. - 180 с.

5. Кунгурская Ледяная пещера: опыт режимных наблюдений / под ред. В.Н. Дублянского. Екатеринбург: УрО РАН, 2005. - 376 с.

6. Лукин В.С., Ежов Ю.А. Карст и строительство в районе г.Кунгура. Методика изысканий и опыт строительства в карстовых областях. - Пермь: Кн. изд-во, 1975. - 120 с.: ил.

УДК 069.014

DOI: 10.7242/echo.2019.1.5

\section{НЕКОТОРЫЕ ИТОГИ РАБОТЫ МУЗЕЯ КАРСТА И СПЕЛЕОЛОГИИ В 2017-2018 ГОДАХ}

\author{
Д.В. НАУМКИН, О.И. ОСЕТРОВА \\ Горный институт УрО РАН, г. Пермь
}

\begin{abstract}
Аннотация: Ведомственный музей карста и спелеологии существует при Кунгурской лабораториистационаре Горного института с 2004 г. Его специализация соответствует тематике исследований лаборатории. В статье рассматриваются результаты работы музея за 2017-2018 гг. по основным направлениям, которые являются общими для всех музейных учреждений страны: экспозиционная, выставочная, фондовая, экскурсионная и издательская деятельность. В течение отчетного периода завершено оформление постоянной экспозиции музея; модифицированы экспозиционные площади выставочного зала; проведено 9 временных выставок, в т.ч. привезенных из других музеев и от частных коллекционеров. Общий фонд поставленных на первичный музейный учет предметов составляет 4126 единиц хранения (2085 основного и 2041 - вспомогательного фонда). В 2018 г. начат второй (тематический) учет экспонатуры. Посещаемость находится на уровне, характерном для муниципальных музеев г. Кунгура - 19 тыс. посетителей за два года. 75\% посетителей - дети. География экскурсионных групп - в основном города и регионы Урала и Сибири (Пермь, Челябинск, Екатеринбург, Тюмень, Омск, Новосибирск, и др.), а также Киров, Казань, Москва, Петербург, Самара, Нижний Новгород, Ижевск. В настоящее время музей стал востребованным и популярным объектом припещерной инфраструктуры.
\end{abstract}

Ключевые слова: музей карста и спелеологии; постоянная экспозиция; выставочный зал; музейные фонды; экскурсии; посещаемость.

В течение 2017-2018 гг. музей карста и спелеологии осуществлял деятельность по нескольким основным направлениям, общим для работы всех музейных учреждений страны. 